\title{
Vitamin D Sufficiency through Sunshine in Infants?
}

\author{
*R GOSWAMI AND"HPS SACHDEV \\ From the Departments of * Endocrinology and Metabolism, AIIMS; and ${ }^{\#}$ Pediatrics and Clinical Epidemiology, \\ Sitaram Bhartia Institute of Science and Research; New Delhi, India. \\ *gosravinder@hotmail.com
}

$\mathrm{V}$ itamin D is vital for human health, and its deficiency may result in hypocalcemic seizures and rickets in infants and children. The optimal cut-off of serum 25(OH)D levels to define vitamin D deficiency are yet to be established. While, the Endocrine Society of USA has suggested serum $25(\mathrm{OH}) \mathrm{D}<20 \mathrm{ng} / \mathrm{mL}$ to define vitamin D deficiency [1], the Institute of Medicine (IOM), USA recommends a cut-off of $12.5 \mathrm{ng} / \mathrm{mL}$ of serum 25(OH)D [2] to define vitamin D deficiency. Despite abundant sunshine, biochemical vitamin D insufficiency and deficiency are reported to be quite prevalent in apparently healthy infants, children, adolescents and pregnant women in urban India [3-5]. Serum 25(OH)D levels $<12.5 \mathrm{ng} / \mathrm{mL}$ were reported in $12-47 \%$ of under-five children and $4-28 \%$ in older children and adolescents [5]. The biological benefits and safety of routine long-term Vitamin D supplementation in breastfed Indian neonates are yet to be unequivocally demonstrated. In a randomized controlled trial from Delhi [6], directly supervised weekly vitamin D supplementation (1400 IU) in term low birth weight newborns for six months expectedly resulted in higher 25(OH)D levels, but there was no decrease in incidence of severe morbidity or death. There were borderline ( $\sim 0.1 \mathrm{SD})$ increases in length, weight and arm circumference, but a paradoxical decrease in head circumference. At age 3-6 years, the supplemented infants were surprisingly borderline $(\sim 0.1 \mathrm{SD})$ thinner but importantly there were no differences in any of the evaluated functional outcomes [7].

The American Academy of Pediatrics [8] and the IOM [2] recommend routine daily supplementation with $400 \mathrm{IU} / \mathrm{d}$ vitamin D in breastfed and partially breastfed infants, beginning in the first few days of life and continued until the infant has been weaned and is drinking at least $1 \mathrm{~L} /$ $\mathrm{d}$ of vitamin D-fortified infant formula or cow milk. Many Indian newborns are now being supplemented with oral vitamin $\mathrm{D}$, despite the fact that the country is blessed with abundant sunshine, the major source of Vitamin D synthesis. It is disappointing that in this era of aggressive pharmacological supplementation and food fortification, natural interventions for attaining vitamin D sufficiency are ignored. Sunlight exposure may be advantageous as it may be safer (hypercalcemia perspective), more costeffective, and offer additional benefits for mood elevation and development and maintenance of circadian rhythm, which is required for normal growth, steroid hormone secretion and sleep pattern.

A recent observational study on adult Indians has documented that sunshine exposure is associated with higher serum 25(OH)D levels [9]. Outdoor manual workers in Delhi had normal vitamin D status with mean serum 25(OH)D values between 20 and $30 \mathrm{ng} / \mathrm{mL}$ [9]. It is possible that the lack of adequate sunshine exposure among mothers and their offspring is resulting in a high prevalence of biochemical vitamin D deficiency. The study by Meena, et al. [10] published in this issue of Indian Pediatrics reminds us of the traditional Indian practice of oil massage and sun-exposure of infants, and enthuses evaluation of sunlight exposure to attain vitamin D sufficiency. The authors advised mothers to expose their newborns to sunshine for a duration of six months, when the association between duration and timing of the sunshine exposure and serum $25(\mathrm{OH}) \mathrm{D}$ was analyzed. Interestingly, with as little as 17 minutes/wk of sunshine exposure, one-third of the infants achieved serum 25(OH)D above $12 \mathrm{ng} / \mathrm{mL}$ (non-deficient). Regression models predicted that a mere $30 \mathrm{~min} /$ week sunshine exposure between 10.00 am and $2.00 \mathrm{pm}$ to prone infants clothed in diapers would result in normal vitamin D level at six months of age. However, in another before-after evaluation in 10- to 15-year-old healthy school children, no increase in serum $25(\mathrm{OH}) \mathrm{D}$ level was documented [11]. These findings may be reflective of suboptimal sunlight exposure in winter months (30 minutes $/ \mathrm{d}$ on $10 \%$ body surface area for 4 weeks). Beforeafter study designs are subject to biases, and hence robust evidence to draft clinical guidelines or policy are only possible from experimental designs. In a randomized controlled trial (RCT) in Netherlands enrolling 232 nonWestern immigrants aged $18-65$ years, effect of vitamin D supplementation ( $800 \mathrm{IU} / \mathrm{d}$ or $100,000 \mathrm{IU}$ every 3 months) 
was compared with advised sunlight exposure [12]. Serum $25(\mathrm{OH}) \mathrm{D}$ increased while serum parathyroid hormone decreased significantly in all groups after 3 months more in the supplementation groups than in the advised sunlight group $(P<0.001$ for the former and $P<0.05$ for the latter). The results of this study are likely to be biased towards vitamin D supplementation because sunlight exposure was advised instead of observed, and the study included elderly participants (vitamin D synthesis from sunlight diminishes in elderly).

In order to meaningfully inform policy, there is an urgent need to conduct an experimental trial comparing the relative efficacy and safety of sunlight exposure and vitamin D supplementation in young infants. Meanwhile it would be pragmatic to promote the customary Indian practice of sunshine exposure in young infants, particularly among the poor who are unable to afford supplementation costs.

Funding: None; Competing interest: None stated

\section{REFERENCES}

1 Holick MF, Binkley NC, Bischoff-Ferrari HA, Gordon CM, Hanley DA, Heaney RP, et al; Endocrine Society. Evaluation, treatment, and prevention of vitamin D deficiency: an Endocrine Society clinical practice guideline. J Clin Endocrinol Metab. 2011;96:1911-30.

2 Institute of Medicine. Dietary Reference Intakes for Calcium and Vitamin D. Washington, DC: The National Academies Press; 2011.

3. Goswami R, Gupta N, Goswami D, Marwaha RK, Tandon N, Kochupillai N. Prevalence and significance of low 25-hydroxyvitamin D concentrations in healthy subjects in Delhi. Am J Clin Nutr. 2000;72:472-5.

4. Kumar GT, Sachdev HS, Chellani H, Rehman AM, Singh V,
Arora $\mathrm{H}$, et al. Effect of weekly vitamin D supplements on mortality, morbidity, and growth of low birthweight term infants in India up to age 6 months: randomised controlled trial. BMJ. 2011;342:d2975.

5. Goswami D, Rani R, Saxena A, Arora MS, Batra S, Sreenivas V. Maternal and neonatal vitamin-D status in twin versus singleton pregnancies. J Obstet Gynaecol Res. 2016;42:1250-7.

6. Trilok Kumar G, Chugh R, Eggersdorfer M. Poor Vitamin D status in healthy populations in India. A review of current evidence. Int J Vitam Nutr Res. 2015;85:185-201.

7 Trilok-Kumar G, Kaur M, Rehman AM, Arora H, Rajput MM, Chugh R, et al. Effects of vitamin D supplementation in infancy on growth, bone parameters, body composition and gross motor development at age 3-6 years: follow-up of a randomized controlled trial. Int $\mathrm{J}$ Epidemiol. 2015;44:894-905.

8 Golden NH, Abrams SA; Committee on Nutrition. Optimizing bone health in children and adolescents. Pediatrics. 2014;134:e1229-43.

9. Goswami R, Saha S, Sreenivas V, Singh N, Lakshmy R. Vitamin D-binding protein, D status and serum bioavailable $25(\mathrm{OH}) \mathrm{D}$ of young Asian Indian males working in outdoor and indoor environments. J Bone Miner Metab. 2016 Jan 30. [Epub ahead of print]

10. Meena P, Dabas A, Shah D, Malhotra RK, Madhu SV, Gupta P. Sunlight exposure and Vitamin D status in breastfed infants. Indian Pediatr. 2017;54:105-11.

11. Marwaha RK, Yenamandra VK, Sreenivas V, Sahay R, Baruah MP, Desai A, et al. Regional and seasonal variations in ultraviolet B irradiation and vitamin D synthesis in India. Osteoporos Int. 2016;27:1611-7.

12. Wicherts IS, Boeke AJ, van der Meer IM, van Schoor NM, Knol DL, Lips P. Sunlight exposure or vitamin D supplementation for vitamin D-deficient non-western immigrants: a randomized clinical trial. Osteoporos Int. 2011;22:873-82. 